v.9, n. 1

Vitória-ES, Jan - Mar 2012

p. $1-24 \quad$ ISSN 1808-2386 DOI: http://dx.doi.org/10.15728/bbr.2012.9.1.1

\title{
Accounting information quality in public stock and bond offerings by brazilian public companies
}

\author{
Edilson Paulo ${ }^{\dagger}$ \\ Universidade Federal da Paraíba - UFPB \\ Paulo Roberto Nóbrega Cavalcante ${ }^{\Omega}$ \\ Universidade Federal da Paraíba - UFPB \\ Iana Izadora Souza Lapa de Melo ${ }^{¥}$ \\ Universidade Federal da Paraíba - UFPB
}

\begin{abstract}
Although bonds account for the largest trading volume of transactions in the Brazilian financial market, most studies of the quality of accounting information focus on the stock market. Considering that many studies suggest that the institutional and organizational environment affects firms' accounting numbers, the following research question can be raised: Is the quality of accounting information affected significantly by public offering of stocks and bonds? To answer this question, we conducted an empirical study of a sample composed of listed Brazilian companies that made public debt and equity offerings between 2000 and 2006. The results indicate that such offerings did not significantly affect the accounting numbers, suggesting that the quality of accounting information is not affected by public stock and bond offerings.
\end{abstract}

Keywords: Accounting information quality; conservatism; persistence; earnings management; accruals.

Received on 12/03/2009; reviewed on 08/25/2011; accepted on 09/20/2011; available in 03/05/2012

Corresponding authors*:

${ }^{+}$Doctor of Science in Accounting from the University of Sao Paulo

Institution: Docente do Programa Multiinstitucional e inter-regional em Ciências Contábeis - UnB/UFPB/UFRN.

Address: Coordenação da Pós-

Graduação em Ciências Contábeis,

Centro de Ciências Contábeis - CCSA -

Campus Universitário I - Bairro Jardim

Cidade Universitária - CEP 58.059-900

- João Pessoa - PB - Brazil

E-mail: epaulo@ccsa.ufpb.br

Telephone: (83) 3216-7285

\author{
${ }^{\Omega}$ Doctor of Science in Accounting from \\ the University of Sao Paulo \\ Institution: Docente do Programa \\ Multiinstitucional e inter-regional em \\ Ciências Contábeis - UnB/UFPB/UFRN. \\ Address: Coordenação da Pós- \\ Graduação em Ciências Contábeis, \\ Centro de Ciências Contábeis - CCSA - \\ Campus Universitário I - Bairro Jardim \\ Cidade Universitária - CEP 58.059-900 \\ - João Pessoa - PB - Brazil \\ Email: paulocavalcante@ccsa.ufpb.br \\ Telephone: (83) 3216-7285
}

\author{
${ }^{¥}$ Master of Science in Accounting \\ Program for multi-institutional and inter- \\ regional in Accounting - UNB / UFPB / \\ UFRN. \\ Address: Endereço Completo: \\ Coordenação da Pós-Graduação em \\ Ciências Contábeis, Centro de Ciências \\ Contábeis - CCSA - Campus \\ Universitário I - Bairro Jardim Cidade \\ Universitária - CEP 58.059-900 - João \\ Pessoa - PB - Brazil \\ E-mail: iana.melo@hotmail.com \\ Telephone: (83) 3216-7285
}

Nota do Editor: Esse artigo foi aceito por Antonio Lopo Martinez. (cc) EY-NG-SA

Esta obra está licenciada sob a Licença Creative Commons - Atribuição-Uso não-comercial-Compartilhamento pela mesma licença 3.0 Unported License 


\section{INTRODUCTION}

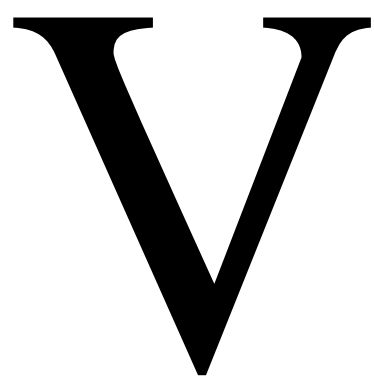

arious studies have examined the characteristics of firms' accounting results and their components (accruals and cash flow) in recent years (Dechow \& Dichev, 2002; Dechow \& Schrand, 2004; Burgstaher; Hail \& Leuz, 2006; Paulo \& Martins, 2007). In these studies, the quality of accounting information is conceived as a broad set of dimensions (attributes), among them persistence, conservatism, earnings management and quality of the estimation of accruals (Dechow \& Dichev, 2002; Dechow \& Schrand, 2004; Burgstaher, Hail \& Leuz, 2006; Dechow, Ge \& Schrand, 2010). Besides these factors, it is important to consider other dimensions (attributes) of accounting information quality, such as transparency, level of disclosure and the relationship of the accounting numbers with the firm's stock price performance and market value.

When a firm makes a public offering of shares or other securities, managers try to obtain the largest volume of resources while investors want to pay the lowest possible price. There is empirical evidence (Teoh, Welch \& Wong, 1998; Roosenboom, Goot \& Mertens, 2003; Morsfield \& Tan, 2006; Paulo, 2006) demonstrating that managers act descretionarily, motivated by the desire to increase the price of the securities offered.

According to $\mathrm{Li}$ (2011), information asymmetry is greater for firms making initial public offerings (IPOs) than for firms that have already gone public because there is less historic information available. Therefore, the same author (2011) states that investors must take greater care in checking the accounting numbers to evaluate IPOs.

Normally studies of accounting choices focus on events at a single moment (Fields, Lys \& Vicent, 2001). However, the accounting choices during a particular fiscal year can have consequences in various subsequent periods, even affecting firms' reputations. According to the theory of adverse selection, the credibility of the financial statements is affected negatively by opportunistic practices involving specific events, which consequently reduce the firm's reputation and increases its cost of capital (Dechow, Ge \& Schrand, 2010).

In the Brazilian capital market, the issuance of securities other than stocks has a relevant participation in the volume of public placements registered with the Brazilian Securities Commission (Comissão de Valores Mobiliários - CVM). Between January 1997 and December 2006, the issuance of bonds accounted for the largest volume of financial resources. Despite the large trading volume in the Brazilian capital market, few studies 
have examined the quality of the accounting information in this setting, particularly the offering of bonds (Martinez \& Faria, 2007).

Therefore, it is important to study the quality of the accounting information disclosed for the purpose of securities offerings by listed Brazilian companies. This leads to the following research question: Is the quality of accounting information significantly affected by public stock and bond offerings?

The objective of this work is to analyze the quality of the accounting information disclosed in the periods before and after public offerings of stocks and bonds by Brazilian public companies, to verify whether there are significant differences in the accounting numbers in the interval studied.

The study was performed with a sample composed of Brazilian public companies that made public stock and bond offerings in the period between 2000 and 2006. It is an empirical study that analyzes the dimensions of the quality of accounting information by applying the models present in the literature to assess the persistence of earnings (Dechow \& Schrand, 2004), level of conservatism (Ball \& Shivakumar, 2005), earnings management (Kang \& Sivaramakrishnan, 1995; PAE, 2005) and quality of estimating accruals (Dechow \& Dichev, 2002). The sample is formed of 436 firm-years.

To analyze whether these four aspects (earnings persistence, conservatism, earnings management and quality of accruals) are significantly different in periods before and after public stock and bond offerings, we tested the hypotheses for differences of the means by analysis of variance (ANOVA) and the Welch and Brown-Forsythe tests (parametric) and the Kruskal-Wallis test (nonparametric), as well as the post-hoc Tukey and Scheffé tests. All the statistical analyses were performed considering a 5\% level of significance (twotailed).

The next section summarizes the relevant literature on the theme, particularly regarding the quality of accounting information and the role of accounting in public securities offerings. The third section presents the methodological procedures employed, and the fourth section describes and analyzes the results. The fifth section concludes.

\section{THEORETICAL FRAMEWORK}

\subsection{Quality of Accounting Information}

Information on economic, social and political activities has been the focus of study in many areas of knowledge. Studying the theme of "information" is a difficult task 
because information is not easy to define and assumes many subjective and mutable characteristics over time, or even from one individual to another (Scott, 2003).

Additionally, a series of social, economic, political and behavioral factors mean that different economic agents do not have the same information in terms of quantity and/or quality. Scott (2003, p. 105) explains that "This situation, in which some participants have better (or more) information than others, is known as information asymmetry".

The influence of accrual basis accounting and other accounting concepts changes according to the institutional and organizational setting in which the firm is inserted, such as the system of governance, auditing, accounting regulations, enforcement of rules, taxation, legal relations under contracts, providers of resources, etc. Therefore, these factors directly affect the quality of the accounting information present in the financial statements published by firms.

Some authors suggest that the quality of accounting information differs between companies due to their greater or lesser reliance on the capital market in relation to other sources of funding, thus influencing the level of monitoring performance by means of disclosure. With respect to the legal system's influence, one of the aspects to consider is the way legislation protects investors from expropriation by managers and controlling shareholders. In general, investors with more and better information are more able to allocate their resources efficiently (Holthausen \& Watts, 2001).

The quality of accounting information can be considered as a set of various dimensions (attributes), such as persistence, conservatism, earnings management, quality of accruals measurement, transparency, level of disclosure and the relation of accounting numbers with stock prices or market value (Dechow, Ge \& Schrand, 2010). This work analyzes the first four of these dimensions: (1) persistence, (2) conservatism, (3) earnings management and (4) quality of accruals.

Dechow \& Schrand (2004, p. 5) consider earnings persistence to be a desirable attribute in evaluating firms' performance, but stress that the quality of this information will be relevant only if the results reported really reflect the performance during the period and if that performance persists in subsequent periods. Accrual basis accounting allows firms to smooth out fluctuations in cash flows, generating a more useful number for investors to make decisions than the operating cash flow in the current period.

The main interest in the persistence of earnings involves the role it plays in forecasting future results, and consequently the value of firms. When errors in estimating accruals occur, for example in marking financial instruments to the market, there is a 
reduction in earnings persistence. This impairs the usefulness of accounting information for the evaluation and prediction of future performance. Dechow (1994), Dechow \& Schrand (2004) and Paulo \& Martins (2007) all show evidence that earnings are more persistent than operating cash flows, so they can be considered a more suitable yardstick to evaluate a firm's performance.

Conservatism is defined as the more timely recognition of bad news than good news (Basu, 1997; Ball \& Shivakumar, 2005). The level of conservatism is affected by the institutional and organization setting, because, as stated by Holthausen \& Watts (2001, p. 37 , conservatism can be related to contractual, litigation and/or tax issues, due to the multiple objectives of financial statements. Lopes (2002, p.42) states that "the general idea of conservatism is to provide more reliable information to investors by means of financial statements that are not excessively optimistic."

Therefore, the practice of conservatism in accounting can minimize opportunistic behavior by managers regarding the accounting numbers, through asymmetry in the verification of accounting numbers, because accounting practices are more demanding in relation to verifying good news than bad news (Paulo \& Martins, 2007, p. 5).

According to Burgstaher, Hail \& Leuz (2006), the level of earnings management is a measure of accounting quality particularly because it is a response to the informational incentives of firms. The broad set of criteria for measuring and disclosing accounting figures allows managers to choose from among valid alternatives to announce numbers in the form desired. Healy \& Wahlen (1999, pp. 368-370) consider earnings management to be a consequence of the discretionary actions of managers to manipulate accounting information about the firm's performance. Scott (2003, p. 369) states that "earnings management is the choice of accounting policy by an administrator in order to reach some specific goals".

Various studies have examined the characteristics of earnings and the respective components (accruals and cash flow), analyzing the impact of the properties of accruals in the process of valuation and contracting. Particular focus is paid to the utility of accruals in predicting future earnings and cash flows, because a firm's capacity to generate earnings and cash flow influences the value of its shares (Dechow, 1994; Lopes, 2002; Dechow \& Dichev, 2002).

Comprehension of the relations among earnings, cash flows and accruals helps in the assessment of firm performance. Dechow (1994) and Dechow \& Dichev (2002) argue 
that accruals adjust the recognition of cash flows over time, making the accounting results a better measure of the firm's performance.

However, since accruals are often based on assumptions and estimates that, if incorrect, must be corrected in future accruals, these adjustments will influence future earnings (Dechow \& Dichev, 2002, p.36). Therefore, measurement errors negatively affect the information content of accruals with respect to future earnings and cash flows. These errors in measuring accruals can be related to the characteristics of the accounting rules of the country and with the accounting policy adopted by the company. This policy, in turn, is affected by the idiosyncrasies of firms.

\subsection{The Importance of Accounting Information in Stock and Bond Offerings}

Choi et al. (1999, pp. 29-31) point out various institutional factors that affect accounting information to different extents, among them the system of financing businesses, concentration of ownership, inflation, the legal system and tax system. They also consider that in countries where the capital market is the main source of financing for companies, such as in the United States and United Kingdom, accounting information is tailored mainly to help investors estimate and value future cash flows. On the other hand, in countries where the debt market is the main source of funding, the accounting system is aimed more at protecting creditors.

According to Niyama (2005, p. 27), even though Brazil does not have a capital market considered to be solid and active, the country has incorporated many of the accounting practices employed in more developed capital markets, where the main concern of providing accounting information is shareholders rather than creditors. Thus, the accounting reports of Brazilian firms try to satisfy the interests of both investors and creditors.

The degree of ownership concentration of firms also influences the demand for accounting information. In countries where shareholding concentration is high, companies internally resolve many of the problems arising from conflicts of interest and asymmetric information, with a direct influence on the quality of the accounting information disclosed (Ball \& Shivakumar, 2005, p. 84).

In the Brazilian capital market, the issuance of securities other than stocks has a relevant participation in the volume of offerings registered with the CVM (Table 1). In 
particular, the public placement of bonds accounts for a much greater volume of financial resources than do stock offerings by Brazilian firms.

Table 1 - Primary offerings registered with the CVM between 1997 and 2006. In millions of reais

\begin{tabular}{|c|c|c|c|c|c|}
\hline Type of Security & 1997 & 1998 & 1999 & 2000 & 2001 \\
\hline Stocks & 3,965 & 4,112 & 2,749 & 1,410 & 1,353 \\
\hline Bonds & 7,518 & 9,657 & 6,676 & 8,748 & 15,162 \\
\hline Promissory Notes & & 12,903 & 8,044 & 7,591 & 5,266 \\
\hline \multirow{2}{*}{\multicolumn{6}{|c|}{$\begin{array}{l}\text { Shares of Receivables Investment Funds/Funds } \\
\text { of Funds }\end{array}$}} \\
\hline & & & & & \\
\hline \multicolumn{6}{|l|}{ Shares of Private Equity Funds/Funds of Funds } \\
\hline Others & 317 & 1,177 & 442 & 1,290 & 1,352 \\
\hline Total & $\mathbf{1 1 , 8 0 0}$ & 27,850 & 17,912 & 19,039 & 23,134 \\
\hline Type of Security & 2002 & 2003 & 2004 & 2005 & 2006 \\
\hline Stocks & 1,050 & 230 & 4,470 & 4,365 & 14,223 \\
\hline Bonds & 14,636 & 5,282 & 9,614 & 41,539 & 69,464 \\
\hline Promissory Notes & 3,876 & 2,128 & 2,241 & 2,632 & 5,279 \\
\hline \multicolumn{6}{|l|}{ Shares of Receivables Investment Funds/Funds } \\
\hline of Funds & & & 5,135 & 8,579 & 12,777 \\
\hline Shares of Private Equity Funds/Funds of Funds & & & & & 4,776 \\
\hline Others & 762 & 2,793 & 2,984 & 4,492 & 3,659 \\
\hline Total & 21,324 & 10,433 & 24,444 & 61,606 & 110,177 \\
\hline
\end{tabular}

Source: Brasil (2007).

Dechow, Ge \& Schrand (2010) report there are incentives in the capital market that influence the choice of the accounting policies adopted by firms. As described previously, according to $\mathrm{Li}$ (2011), due to the lack of historic information about companies launching IPOs, investors must rely strongly on the information reported in the prospectuses. In contrast, bond issues are evaluated by rating agencies, which use a range of information about the company to attribute a risk level to the papers to be issued.

Since accounting information is an important source for investors to reach decisions about both debt and equity securities, managers have incentives to act opportunistically with the aim of improving the rating attributed to the firm's publicly traded papers, to decrease the cost of capital.

Agency theory establishes that individuals act to maximize their own utilities. According to Watts \& Zimmerman (1986, p. 3), at the time of deciding on what accounting 
information to disclose and how to do so, individuals try to know the way measurement and disclosure alternatives will affect their wealth. Under the prism of agency theory, accounting information is influenced directly by the personal interests of the principals and agents (respectively the stockholders and managers) (Watts \& Zimmerman, 1986; Beaver, 1998; Scott, 2003; Lopes \& Martins, 2005).

According to $\mathrm{Yu}$ (2005), analysts affect the flow of information about firms, and thus the discretion of managers in reporting accounting numbers. Various studies have shown evidence of earnings management (Jones, 1991; Martinez, 2001). Some of these have focused specifically on the influence of analysts' coverage on the performance of the accounting numbers of the firms analyzed (Yu, 2005; Paulo, 2006).

In a paper examining the occurrence of earnings management in the periods before and after public stock offerings, Paulo (2006) found that listed Brazilian companies use accruals to improve their accounting numbers just before launching stock offerings, so as to influence the price obtained.

Nevertheless, despite the relevance of the corporate bond market in Brazil, few studies have examined the dimensions of the quality of accounting numbers in relation to the public issuance of bonds in the country. It is thus relevant to undertake this effort.

\section{METHODOLOGY}

\subsection{Type of Study}

This is an empirical study, relying on some of the leading econometric models described in the specific literature to verify whether there are significant differences in the quality of accounting information in the periods before and after the moment of stock and bond offerings by Brazilian public companies.

\subsection{Development of the Hypotheses and Definition of the Models}

To satisfy the research objectives, we formulated some hypotheses about the dimensions of the quality of financial information related to public issuance of stocks and bonds in the Brazilian market.

Studies of the persistence of earnings are motivated by the assumption that this persistence provides useful information to value stocks and other securities in the capital market. According to Dechow \& Skinner (2000; p.238), accrual basis accounting tends to smooth out fluctuations in firms' cash flows, generating numbers that are more useful to investors than the cash flow for just the current period. Thus, the reason for the strong 
interest in earnings persistence is the role this exercises on the prediction of future earnings, and hence on the value of securities.

Therefore, in light of the importance or earnings persistence in the process of evaluating firms' performance, and consequently on the pricing of the securities offered in the capital market, as well as the evidence that earnings are more persistent than cash flow, our first hypothesis is the following:

Hypothesis 1: Earnings are more persistent than cash flow in the periods around public offerings of stocks and bonds in the Brazilian market.

Since more persistent earnings indicate less volatility (risk), which leads to lower cost of capital and higher securities prices, the earnings before a public offering should be more persistent than those afterward. This suggests the following hypothesis:

Hypothesis 2: The persistence of earnings is significantly different in the periods before and after public offerings of stocks and bonds by Brazilian public companies.

To verify the persistence of earnings and cash flows, we used the following model (Dechow \& Schrand, 2004, p.12):

$X_{i t+1}=\alpha_{0}+\alpha_{1} X_{i t}+\varepsilon_{i t}(1)$

where:

$X_{i t+1}=$ value of the variable (earnings or cash flow) of firm $i$ in year $t+1$;

$X_{i t} \quad=$ value of the variable (earnings or cash flow) of firm $i$ in year $t$;

$\varepsilon_{i t} \quad=$ regression error.

All the variables are weighted by total assets at the start of the period.

To analyze the differences in characteristics of accounting information of the sample companies, we considered that the firm with the highest estimated coefficient $\alpha_{1}$ is the one with the most persistent earnings and cash flow.

As described previously, the academic literature suggests that more conservative numbers imply better quality of accounting earnings (Dechow, Ge \& Schrand, 2010), and for the purpose of influencing the pricing of securities, firms should be more conservative in reporting their earnings in the period leading up to public securities offerings. Due to the relevance of conservatism on the accounting numbers at the moment of public securities offerings, our third hypothesis is: 
Hypothesis 3: The level of accounting conservatism by Brazilian public companies is greater in the period before public stock and bond offerings than in the subsequent period.

To measure the level of conservatism, we used the model proposed by Ball \& Shivakumar (2005, p. 92), described in the following form:

$\Delta N I_{i t}=\alpha_{0}+\alpha_{1} D \Delta N I_{i t-1}+\alpha_{2} \Delta N I_{i t-1}+\alpha_{3} \Delta N I_{i t-1} * D \Delta N I_{i t-1}+\varepsilon_{i t}(2)$

where:

$\Delta N I_{i t}=$ variation of net income of firm $i$ from year $t-1$ tp year $t$;

$\Delta N I_{i t-1}=$ variation of net income of firm $i$ from year $t-2$ to year $t-1$;

$D \Delta N I_{i t-1}=$ dummy variable to indicate the existence of a negative variation in the net

income of firm $i$ from year $t-1$ tp year $t$, assuming the value 1 if $\Delta N I_{i t}<0$, and 0 otherwise;

$\varepsilon_{i t} \quad=$ regression error.

All the variables are weighted by total assets at the start of the period.

In this model (Equation 2), the use of "variation in net income" as the independent variable has the advantage of providing an adequate specification to identify the temporary components of earnings (Ball \& Shivakumar, 2005, p. 92). The hypothesis assumed by those authors is that there is less reversal of income decreases in less conservative companies, reflecting less timely recognition of losses, due to lower demand for conservative behavior in the measurement of accounting information.

The coefficient $\alpha_{2}$ should be equal to zero $\left(\alpha_{2}=0\right)$, because due to the deferred recognition of economic gains until the moment when the cash flow is realized, positive results become a persistent component of accounting income, which tends to be reversed (Ball \& Shivakumar, 2005, p. 95). In the case of timely recognition, gains become a transitory component of income and tend to be reversed in subsequent periods. This implies that the coefficient $\alpha_{2}$ is less than zero $\left(\alpha_{2}<0\right)$.

On the other hand, the timelier recognition of losses than gains implies that the coefficient $\alpha_{3}$ is lower than zero $\left(\alpha_{3}<0\right)$. By the same reasoning, the timely recognition of losses results in transitory decreases in net income and consequently these losses must be reversed in subsequent periods, implying a priori that the sum of the coefficients $\alpha_{2}$ and $\alpha_{3}$ is less than zero $\left(\alpha_{2}+\alpha_{3}<0\right)$. There is no prediction for the linear coefficients (intercepts) $\alpha_{0}$ and $\alpha_{l}$ in this model. 
As described previously, at the time of making a public security offering, managers seek to maximize the funds raised. This natural attitude increases the likelihood that managers will act discretionarily with the objective or raising the price at the moment of issuing stocks or other securities. There is empirical evidence corroborating this hypothesis in the international literature (Teoh, Welch \& Wong, 1998; Roosenboom, Goot \& Mertens, 2003; Darrough \& Rangan, 2005). Therefore, with respect to earnings management it is important to identify the level of opportunistic behavior in the periods before and after public offerings of stocks and bonds, bringing the following hypothesis:

Hypothesis 4: The level of earnings management is significantly higher in the period before public offerings of stocks and bonds by Brazilian public companies.

The proxy for earnings management used here was nondiscretionary accruals $\left(N D A_{i t}\right)$, estimated by the models proposed by Kang \& Sivaramakrishnan (1995, p. 353) and Pae (2005, p. 6). Martinez (2001) shows evidence that the KS model produces better results in the Brazilian context. According to this model, nondiscretionary accruals are estimated through the following regression (Equation 3):

$T A_{i t}=\Phi_{0}+\Phi_{1}\left(\delta_{1} R_{i t}\right)+\Phi_{2}\left(\delta_{2} \operatorname{Exp}_{i t}\right)+\Phi_{3}\left(\delta_{3} P P E_{i t}\right)+\varepsilon_{i t}(3)$

where:

$T A_{i t}=$ total accruals of firm $i$ in period $t$;

$R_{i t} \quad=$ net revenue of firm $i$ in period $t$;

$\operatorname{Exp}_{i t}=$ operating costs and expenses of firm $i$ in period $t$, excluding depreciation and amortization expenses;

$P P E_{i t}=$ balance of property, plant and equipment and deferred charges (gross) of firm $i$ at the end of period $t$;

$\delta_{1} \quad=C R_{i, t-1} / R_{i, t-1}$

$\delta_{2}=\left(I N V_{i, t-1}+\operatorname{PrepExp}_{i, t-1}+C P_{i, t-1}\right) / D_{i, t-1}$;

$\delta_{3}=\operatorname{Depr}_{i, t-1} / P P E_{i, t-1}$;

$A R_{i-1 t}=$ balance of short-term accounts receivable of firm $i$ in period $t-1$;

$R_{i, t-1}=$ net revenue of firm $i$ in period $t-1$;

$I N V_{i, t-1} \quad=$ balance of inventories of firm $i$ in period $t-1$;

PrepExp $_{i, t-1}=$ balance of prepaid expenses of firm $i$ in period $t-1$;

$A P_{i, t-1}=$ balance of short-term accounts payable of firm $i$ in period $t-1$; 
Depr $_{i, t-1} \quad=$ amount of expenses for depreciation and amortization of firm $i$ in period $t-1$;

$P P E_{i, t-1}=$ balance of property, plant and equipment and deferred charges (gross) of firm $i$ at the end of period $t-1$;

$\varepsilon_{i t} \quad=$ regression error.

All the variables are weighted by total assets at the start of period $t$.

The model proposed by Pae (2005, p. 6) aims to increase the predictive power of the Jones and modified Jones models by including variables that represent operating cash flow and natural reversal of previous accruals (Paulo, 2007). The general model proposed by Pae (2005) is described in the following form (Equation 4):

$T A_{i t}=\alpha\left(1 / A_{t-1}\right)+\beta_{1}\left(\Delta R_{i t}\right)+\beta_{2}\left(P P E_{i t}\right)+\beta_{3}\left(C F O_{i t}\right)+\beta_{4}\left(C F O_{i t-1}\right)+\beta_{5}\left(T A_{i t-1}\right)+\varepsilon_{i t}(4)$

where:

$T A_{i t}=$ total accruals of firm $i$ in period $t$

$\Delta R_{i t} \quad=$ variation of net revenue of firm $i$ from period $t-1$ to period $t$;

$P P E_{i t}=$ balance of property, plant and equipment and deferred charges (gross) of firm $i$ at the end of period $t$;

$A_{i t-1}=$ total accruals of firm $i$ at the end of period $t-1$;

$C F O_{i t}=$ operating cash flow of firm $i$ in period $t$;

$C F O_{i t-1}=$ operating cash flow of firm $i$ in period $t-1$;

$T A_{i t} \quad=$ total accruals of firm $i$ in period $t$;

$\varepsilon_{i t} \quad=$ regression error;

All the variables are weighted by total assets at the start of period $t$.

For the two models utilized, total accruals are calculated as follows (Paulo, 2007):

$T A_{i t}=\left(\Delta C A_{i t}-\Delta C C E_{i t}\right)-\left(\Delta C L_{i t}-\Delta D e b t_{i t}\right)-\operatorname{Depr}_{i t}(5)$

where:

$T A_{i t} \quad=$ total accruals of firm $i$ in period $t$;

$\Delta C A_{i t}=$ variation of current assets of firm $i$ from the end of period $t-1$ to the end of period $t$

$\Delta C L_{i t}=$ variation of current liabilities of firm $i$ from the end of period $t-1$ to the end of period $t$;

$\triangle C C E p_{i t} \quad=$ variation of cash and cash equivalents of firm $i$ from the end of period $t-1$ to the end of period $t$; 
$\Delta$ Debt $_{i t} \quad=$ variation of short-term loans and financing of firm $i$ from the end of period $t-1$ to the end of period $t$;

Depr $_{i t}=$ amount of depreciation and amortization expenses of firm $i$ during period $t$;

All the variables are weighted by total assets at the start of period $t$.

Finally, based on the nondiscretionary accruals estimated by the KS and Pae models, the discretionary accruals of firm $i$ in period $t$ are calculated as follows (Paulo, 2007):

$D A_{i t}=T A_{i t}-N D A_{i t}(6)$

where:

$D A_{i t}=$ discretionary accruals of firm $i$ in period $t$;

$T A_{i t} \quad=$ total accruals of firm $i$ in period $t$;

$N D A_{i t}=$ nondiscretionary accruals of firm $i$ in period;

All the variables are weighted by total assets at the start of period $t$.

We consider that a higher standard deviation of discretionary accruals indicates a greater likelihood of earnings management, and consequently lower quality of earnings. The use of the standard deviation of discretionary accruals as a measure of earnings management is due to the fact that a larger volume of accruals (discretionary and nondiscretionary) might be caused by the particular characteristics of a determined economic sector, affecting the process of measuring and estimating accruals.

Finally, accruals are often based on assumptions and estimates that, if incorrect, affect future accruals and earnings. Therefore, errors in their measurement negatively influence the information content of accruals regarding future earnings and cash flows, which impairs the proper valuation of securities by investors. Based on this, the following hypothesis can be proposed:

Hypothesis 5: The quality of the estimations of the accruals reported by Brazilian public companies is significantly affected by the public stock and bond offerings.

Since the amount of accruals is similar to the past and future cash flows plus the respective adjustments due to past estimation errors, according to Dechow \& Dichev (2002) the following model can be employed to measure the quality of accruals:

$$
\Delta W C_{t}=\alpha_{0}+\beta_{1}\left(C F_{t-1}\right)+\beta_{2}\left(C F_{t}\right)+\beta_{3}\left(C F_{t+1}\right)+\varepsilon_{t}
$$


where:

$\Delta W C_{t}=$ variation of working capital accruals of the firm from period $t-1$ to period $t$, weighted by total assets at the end of period $t-1$;

$C F_{t-1}=$ cash flows in period $t-1$, weighted by total assets at the end of period $t-2$;

$C F_{t} \quad=$ cash flows in period $t$, weighted by total assets at the end of period $t-1$;

$C F_{t+1}=$ cash flows in period $t+1$, weighted by total assets at the end of period $t$;

$\varepsilon_{t}=\quad$ accruals estimation error in period $t$;

$\alpha, \beta_{1}, \beta_{2}$ and $\beta_{3}=$ coefficients estimated from the regression in Equation 7.

According to Dechow \& Dichev (2002), the residuals of this regression are the accruals that are associated with the realization of the cash flows and the standard deviation of these residuals is a measure of the quality of accruals. According to this conjecture, the greater the standard deviation, the lower the quality of accruals.

In this work we used dummy variables to control for the peculiar characteristics of each economic sector, for the purpose of estimating more consistent parameters.

\subsection{Sample}

The sample of this study consisted of the set of Brazilian public companies that issued stocks of bonds to the public in the period from 2000 to 2006 . We obtained the data from the databases of Economática and the Brazilian Securities Commission (CVM). To avoid bias in the sample and specification problems, we eliminated companies that did not have all the necessary data for this study.

To obtain more robust empirical data, companies that presented data in any one year farther than four standard deviations above and below the mean (outliers) were excluded from the sample. This procedure is consistent with previous empirical studies (Subramanyam, 1996). However, the results of the analysis without excluding these outliers were not significantly different.

Based on these procedures, the final sample was formed of 436 firm-years.

\section{.4. PRSENTATION AND ANALYSIS OF THE DATA}

Tables 2 and 3, respectively, show the parameters and statistics of the models utilized to analyze the persistence of earnings and operating cash flows. 
Table 2 - Analysis of the persistence of earnings

\begin{tabular}{|c|c|c|c|c|c|c|c|c|c|}
\hline & \multicolumn{4}{|c|}{ Stock Issue } & \multicolumn{4}{|c|}{ Bond Issue } \\
\hline & & $\mathbf{t}_{-2}$ & $\mathbf{t}_{-1}$ & $\mathbf{t}_{0}$ & $\mathbf{t}_{1}$ & $\mathbf{t}_{-2}$ & $\mathbf{t}_{-1}$ & $\mathbf{t}_{0}$ & $\mathbf{t}_{1}$ \\
\hline \multirow[t]{2}{*}{ Constant } & coeffic. & 0.039 & 0.079 & 0.062 & -0.007 & 0.014 & 0.030 & -0.033 & 0,022 \\
\hline & p-value & 0.034 & 0.595 & 0.007 & 0.723 & 0.152 & 0.015 & 0.113 & 0,038 \\
\hline \multirow[t]{2}{*}{$\mathrm{LO}_{\text {it }}$} & coeffic. & 0.662 & 1.802 & 0.001 & 0.761 & 0.506 & 0.000 & 1.336 & 0,433 \\
\hline & p-value & 0.002 & 0.056 & 0.003 & 0.000 & 0.000 & 0.706 & 0.000 & 0,000 \\
\hline \multicolumn{2}{|l|}{$\mathrm{R}^{2}$} & 0.162 & 0.062 & 0.191 & 0.532 & 0.410 & 0.000 & 0.439 & 0,555 \\
\hline \multicolumn{2}{|c|}{ Observations } & 54 & 58 & 64 & 45 & 53 & 53 & 59 & 50 \\
\hline
\end{tabular}

Table 3 - Analysis of the persistence of operating cash flows

\begin{tabular}{|c|c|c|c|c|c|c|c|c|c|}
\hline & & \multicolumn{4}{|c|}{ Stock Issue } & \multicolumn{4}{|c|}{ Bond Issue } \\
\hline & & $t_{-2}$ & $t_{-1}$ & $\mathbf{t}_{0}$ & $\mathbf{t}_{1}$ & $t_{-2}$ & $t_{-1}$ & $\mathbf{t}_{0}$ & $\mathbf{t}_{1}$ \\
\hline \multirow[t]{2}{*}{ Constant } & coeffic. & 0.026 & 0.017 & 0.164 & 0.144 & 0.078 & 0.193 & 0.162 & 0,114 \\
\hline & p-value & 0.393 & 0.630 & 0.000 & 0.000 & 0.018 & 0.000 & 0.026 & 0,000 \\
\hline \multirow[t]{2}{*}{$\mathrm{CFO}_{\text {it }}$} & coeffic. & 0.918 & 0.880 & 0.001 & 0.226 & 0.412 & 0.000 & 0.070 & 0,214 \\
\hline & $\mathrm{p}$-value & 0.000 & 0.000 & 0.066 & 0.232 & 0.004 & 0.334 & 0.818 & 0,033 \\
\hline \multicolumn{2}{|l|}{$\mathrm{R}^{2}$} & 0.499 & 0.443 & 0.160 & 0.053 & 0.239 & 0.026 & 0.002 & 0,134 \\
\hline \multicolumn{2}{|c|}{ Observations } & 54 & 58 & 64 & 45 & 53 & 53 & 59 & 50 \\
\hline
\end{tabular}

It can be seen in Table 2 that the model used to analyze the persistence of earnings has an $\mathrm{R}^{2}$ that fluctuates strongly in the periods around the issuance of stocks (between 0.062 and 0.532) and bonds (between 0.000 and 0.555). In turn, for persistence of operating cash flows, Table 3 shows that the explanatory power of the model in terms of $\mathrm{R}^{2}$ behaved the same way as for earnings, both for firms that issued stocks (between 0.053 and 0.499 ) and those that issued bonds (between 0.002 and 0.239 ).

Analysis of the coefficients of the explanatory variables for persistence of earnings $\left(\mathrm{LO}_{i t}\right)$ and cash flows $\left(\mathrm{CFO}_{i t}\right)$ shows that current earnings are more persistent in future earnings than are current cash flows in future ones, except for the period $t-2$ for the companies in the sample that issued stocks. Therefore, this evidence confirms the first hypothesis, that earnings are more persistent than operating cash flows.

Comparison between the persistence of earnings in the periods before and after stock issues showed significant differences between the coefficients $\alpha_{1}$, with greater persistence in the year before issuance than in the year afterward. However, for bond 
issues, the sample firms' earnings persistence was lower in the year beforehand. Therefore, the second hypothesis, according to which earnings are more persistent in the year before public securities offerings than in subsequent years, was only confirmed for stock offerings. Additionally, the same behavior occurred for operating cash flow. A possible explanation for the failure to confirm the hypothesis for the sample of firms issuing bonds is that risk analysts do not observe the persistence of earnings in their evaluations, so managers do not have incentives to seek this characteristic. Or it might be that this attribute of the quality of earnings is reached more quickly, in the quarterly financial reports that precede the offering. We did not analyze these possible explanations.

Table 4 presents the estimates of the model for analysis of conservatism (Equation 2). At a $5 \%$ significance level, the coefficient of the variable $\Delta \mathrm{NI}_{\mathrm{it}-1}\left(\alpha_{2}\right)$ is statistically equal to zero, because the p-value is greater than 0.05 (Wooldridge, 2002), except for the two previous years in the sample of firms that issued stocks. This confirms the prediction in the current literature that positive results become persistent components of earnings and are not reversed in subsequent periods. But the coefficient of the variable $\Delta \mathrm{NI}_{\mathrm{it}-1}{ }^{*} \mathrm{D} \Delta \mathrm{NI}_{\mathrm{it}-1}$ $\left(\alpha_{3}\right)$ is only significantly lower than zero $\left(\alpha_{3}<0\right)$ for the period t-2 of the sample of firms that issued stocks.

Table 4 - Analysis of the conservatism of earnings reporting

\begin{tabular}{|c|c|c|c|c|c|c|c|c|c|c|}
\hline & & & \multicolumn{4}{|c|}{ Stock Issue } & \multicolumn{4}{|c|}{ Bond Issue } \\
\hline & & & $t_{-2}$ & $t_{-1}$ & $\mathbf{t}_{\mathbf{0}}$ & $\mathbf{t}_{1}$ & $t_{-2}$ & $t_{-1}$ & $\mathbf{t}_{0}$ & $\mathbf{t}_{1}$ \\
\hline \multirow{2}{*}{\multicolumn{2}{|c|}{ Constant }} & coeffic. & -0.021 & -0.014 & 0.233 & 0.007 & -0.005 & -1.781 & -0.005 & -0.009 \\
\hline & & p-value & 0.268 & 0.618 & 0.237 & 0.803 & 0.863 & 0.620 & 0.700 & 0.825 \\
\hline \multirow{2}{*}{\multicolumn{2}{|c|}{$\mathrm{D} \Delta \mathrm{NI}_{\mathrm{it}-1}$}} & coeffic. & 0.006 & 0.011 & -0.205 & 0.040 & -0.013 & 1.783 & 0.034 & 0.015 \\
\hline & & p-value & 0.878 & 0.793 & 0.586 & 0.307 & 0.767 & 0.754 & 0.033 & 0.795 \\
\hline \multirow{2}{*}{\multicolumn{2}{|c|}{$\Delta \mathrm{NI}_{\mathrm{it}-1}$}} & coeffic. & 0.642 & 0.528 & -0.005 & 0.221 & 0.121 & -21.370 & 0.166 & -0.525 \\
\hline & & p-value & 0.003 & 0.002 & 0.996 & 0.454 & 0.756 & 0.317 & 0.288 & 0.476 \\
\hline \multicolumn{11}{|l|}{$\Delta \mathrm{NI}_{\mathrm{it}-1}$} \\
\hline \multirow{2}{*}{\multicolumn{2}{|c|}{$\mathrm{D} \Delta \mathrm{NI}_{\mathrm{it}-1}$}} & coeffic. & -1.327 & -0.899 & 0.526 & -0.241 & -0.808 & 20.803 & -0.164 & 0.585 \\
\hline & & p-value & 0.005 & 0.622 & 0.934 & 0.402 & 0.139 & 0.679 & 0.288 & 0.571 \\
\hline $\mathrm{R}^{2}$ & & & 0.269 & 0.188 & 0.011 & 0.477 & 0.078 & 0.036 & 0.077 & 0.022 \\
\hline Observat & & & 54 & 58 & 64 & 45 & 53 & 53 & 59 & 50 \\
\hline
\end{tabular}


The estimates presented in Table 4 demonstrate that the sum of the coefficients $\alpha_{2}$ and $\alpha_{3}$ is less than zero $\left(\alpha_{2}+\alpha_{3}<0\right)$, except for the year of bond offerings and the year afterward. In the case of stock offerings, the sum of the same coefficients in period $t_{-1}$ ($0.371)$ is lower than the sum in period $t_{1}(-0.020)$, corroborating Hypothesis 3. However, the numbers present inconclusive empirical evidence on the timely recognition of losses, because the third hypothesis cannot be confirmed for bond issues. Furthermore, the predictive power of the model used (Equation 2) to analyze conservatism is low, with a widely fluctuating $\mathrm{R}^{2}$ value in the period analyzed.

To assess the level of earnings management, we used the standard deviation of the discretionary accruals estimated by the models of Kang \& Sivaramakrishnan (1995) and Pae (2005). Table 5 shows the mean discretionary accruals and the respective standard deviations estimated by the two models for each period analyzed, along with the coefficient of determination $\left(R^{2}\right)$ and number of observations.

Table 5 - Analysis of earnings management

\begin{tabular}{|c|c|c|c|c|c|c|c|c|c|}
\hline & & \multicolumn{4}{|c|}{ Stock Issue } & \multicolumn{4}{|c|}{ Bond Issue } \\
\hline & & $t_{-2}$ & $t_{-1}$ & $\mathbf{t}_{\mathbf{0}}$ & $\mathbf{t}_{1}$ & $\mathbf{t}_{-2}$ & $t_{-1}$ & $\mathbf{t}_{0}$ & $\mathbf{t}_{1}$ \\
\hline \multirow[t]{2}{*}{$\mathrm{KS}$} & Mean & 0.035 & 0.062 & 0.057 & 0.002 & -0.003 & 0.036 & 0.011 & -0.051 \\
\hline & Standard dev. & 0.103 & 0.099 & 0.646 & 0.163 & 0.143 & 0.135 & 0.200 & 0.182 \\
\hline \multirow[t]{3}{*}{$\mathrm{Pae}$} & Mean & 0.035 & 0.052 & -0.001 & -0.004 & 0.013 & 0.006 & -0.018 & -0.015 \\
\hline & Standard dev. & 0.090 & 0.063 & 0.141 & 0.139 & 0.101 & 0.070 & 0.100 & 0.158 \\
\hline & Observations & 54 & 58 & 64 & 45 & 53 & 53 & 59 & 50 \\
\hline
\end{tabular}

To check if the differences between the means are statistically significant, we used ANOVA and the Welch and Brown-Forsythe tests. The second two are preferable when the assumption of homogeneity of the variances is not observed (Merino \& Díaz, 2002). We checked this homogeneity by the Levene test. To obtain more robust results, we also applied the nonparametric Kruskal-Wallis test to verify if the discretionary accruals are statistically different, since in this test it is not necessary for the data to be normally distributed or for the variances to be homogeneous. 
Table 6 - Tests of homogeneity of the variance and comparison of the means of discretionary accruals

\begin{tabular}{|c|c|c|c|c|}
\hline & \multicolumn{2}{|c|}{ Stock Issue } & \multicolumn{2}{|c|}{ Bond Issue } \\
\hline & statistic & p-value & Statistic & $p$-value \\
\hline \multicolumn{5}{|l|}{ Panel A - KS Model } \\
\hline Kolmogorov-Smirnov & 3.662 & 0.000 & 6.273 & 0.000 \\
\hline Levene & 6.293 & 0.000 & 3.694 & 0.013 \\
\hline ANOVA & 0.262 & 0.853 & 1.210 & 0.307 \\
\hline Welch & 1.726 & 0.165 & 1.071 & 0.365 \\
\hline Brown-Forsythe & 0.352 & 0.788 & 1.158 & 0.335 \\
\hline Kruskal-Wallis & 5.812 & 0.121 & 2.424 & 0.489 \\
\hline \multicolumn{5}{|l|}{ Panel B - Pae Model } \\
\hline Kolmogorov-Smirnov & 2.080 & 0.000 & 1.414 & 0.037 \\
\hline Levene & 1.727 & 0.165 & 2.009 & 0.116 \\
\hline ANOVA & 1.794 & 0.152 & 0.572 & 0.634 \\
\hline Welch & 2.419 & 0.074 & 0.724 & 0.541 \\
\hline Brown-Forsythe & 1.953 & 0.125 & 0.596 & 0.619 \\
\hline Kruskal-Wallis & 3.384 & 0.336 & 2.810 & 0.422 \\
\hline
\end{tabular}

Based on the Kolmogorov-Smirnov test (Table 6), there is evidence to reject the normality of the discretionary accruals estimated by the two models. In other words, the discretionary accruals are not normally distributed. According to the Levene test (Table 5), applied to analyze the existence of equality of the variances of the groups, the accruals estimated by the Pae model have homogeneous variances for the two samples analyzed, while this is not the case for the accruals estimated by the KS model.

Therefore, since the data analyzed are not normally distributed and the variances are not homogeneous, it is more suitable to use nonparametric statistical tests. Nevertheless, we also applied parametric techniques with the aim of presenting more empirical evidence.

The results of all the tests, both the parametric ones (ANOVA, Welch and BrownForsythe) and nonparametric one (Kruskal-Wallis), employed to analyze the differences in the average accruals in the periods before and after issuance of stocks and bonds by Brazilian public companies (Table 6), show there are no statistically significant differences between the average accruals in the periods close to public offerings, in all the samples. Thus, the fourth hypothesis, according to which firms manage earnings more in periods before the public issuance of stocks and bonds, cannot be confirmed. 
Table 7 - Statistics for analysis of the quality of accruals

\begin{tabular}{|c|c|c|c|c|c|c|c|c|}
\hline & \multicolumn{4}{|c|}{ Stock Issue } & \multicolumn{4}{|c|}{ Bond Issue } \\
\hline & $\mathbf{t}_{-2}$ & $\mathbf{t}_{-1}$ & $\mathbf{t}_{0}$ & $\mathbf{t}_{1}$ & $\mathbf{t}_{-2}$ & $\mathbf{t}_{-1}$ & $t_{0}$ & $\mathbf{t}_{1}$ \\
\hline Mean & 0.046 & 0.077 & 0.034 & 0.054 & 0.020 & 0.018 & -0.009 & 0.214 \\
\hline Standard dev. & 0.102 & 0.071 & 0.129 & 0.069 & 0.086 & 0.082 & 0.120 & 0.167 \\
\hline Observations & 54 & 58 & 64 & 45 & 53 & 53 & 59 & 50 \\
\hline
\end{tabular}

Table 7 presents the means and standard deviations of the accruals estimated by the model of Dechow \& Dichev (2002), which evaluates the quality of accruals. As defined by the two authors, the standard deviation of the accruals is a measure of their quality.

According to the data presented in Table 8, the standard deviations of the accruals are normally distributed (Kolmogorov-Smirnov test) and the variances are equal (Levene test), in both cases at a $5 \%$ level of significance $(\alpha=0.05)$. To verify if the differences between the standard deviations of the accruals are statistically significant, we also applied ANOVA and the Welch, Brown-Forsythe and Kruskal-Wallis tests.

Table 8 - Homogeneity of the variance and comparison of the means tests

\begin{tabular}{l|l|l|l|l}
\hline \multirow{2}{*}{} & \multicolumn{2}{l}{ Stock Issue } & \multicolumn{2}{l}{ Bond Issue } \\
\cline { 2 - 5 } & statistic & $p$-value & statistic & $p$-value \\
\hline Kolmogorov-Smirnov & 1.251 & 0.087 & 1.318 & 0.062 \\
\hline Levene & 2.344 & 0.077 & 1.465 & 0.228 \\
\hline ANOVA & 1.022 & 0.386 & 0.463 & 0.709 \\
\hline Welch & 1.152 & 0.336 & 0.479 & 0.698 \\
\hline Brown-Forsythe & 1.064 & 0.369 & 0.467 & 0.706 \\
\hline Kruskal-Wallis & 5.329 & 0.149 & 2.116 & 0.549 \\
\hline
\end{tabular}

From the results shown in Table 8 , there is no evidence that the errors in the accruals estimated by the model proposed by Dechow \& Dichev (2002) are significantly different in the periods before and after public issuance of stocks and bonds by Brazilian firms. Therefore, these results indicate there are no differences in the informational quality of the accruals estimated in the periods around the issuance of stocks and bonds. 


\section{FINAL CONSIDERATIONS}

The objective of this study was to present empirical evidence to help better understand the quality of accounting information, specifically of earnings persistence, conservatism, earnings management and quality of accruals. A better understanding of the characteristics of accounting information is relevant because it facilitates the economic and financial analysis of companies, contributing to better allocation of financial resources. This work specifically analyzed these attributes of accounting information in the periods before and after the public issuance of stocks and bonds by Brazilian public companies.

The results provide evidence that the earnings reported by Brazilian firms in the periods before and after stock and bond offerings are more persistent than cash flows, corroborating the empirical evidence presented by other authors. This suggests that earnings have more informational content than cash flows to evaluate the performance of Brazilian firms.

The evidence supports the hypothesis raised here that the earnings in the period before public stock offerings are more persistent than those reported in subsequent years for the sample. However, this hypothesis was not confirmed for firms issuing bonds. But there was less earnings persistence in the year of stock offerings and in the year before bond offerings. This evidence suggests that in the period near the issuance of these securities, Brazilian firms may modify their accounting practices, causing higher volatility of the accounting numbers, especially earnings. But this change is not necessarily related to opportunistic behavior of managers, because it might also be related to the adoption of accounting practices required by the Brazilian Securities Commission (CVM) at the time of public bond placements.

With respect to conservatism, the results presented are not satisfactory, impairing any inferences about the evidence presented. This difficulty is related to the low predictive power of the operational model employed to measure the firms' conservatism in the periods around the issuance of stocks and bonds. Because of the weak forecasting power of the operational models used in the national and international literature, we suggest that future works on conservatism develop new metrics to measure this attribute of information quality more reliably.

The findings here also do not suggest the existence of opportunistic behavior prompted by public issuance of stocks and bonds in the Brazilian market. However, this evidence should be taken with caution, because the models employed here in this respect also have low predictive power, hindering the inferences that can be made. 
Finally, the analysis of the quality of accounting information by measurement of errors in accruals showed no significant differences in these errors in the periods before and after stock and bond offerings. This evidence suggests there are no differences in the quality of the accounting information disclosed by Brazilian firms in the years before and after issuing equity and debt securities.

Based on the evidence presented here, not all the information quality attributes are influenced by public stock and bond offerings in Brazil. Therefore, in general lines, the results suggest that the accounting numbers are not significantly different in the periods just before and after the issuance of stocks and bonds.

Nevertheless, further research is necessary on the influence of peculiar characteristics of economic events and transactions on the quality of accounting information. In this respect, we suggest that future studies analyze the quality of accounting information in various business environments. Besides this, the empirical models employed in the literature do not always have satisfactory explanatory power to analyze the hypotheses raised in this study, so there is a need to develop new econometric models that take into consideration the particular characteristics of the local market.

\section{REFERENCES}

BASU, Sudipta. The conservatism principle and the asymmetric timeliness of earnings. Journal of Accounting and Economics, New York: v. 24, v.1, p.3-37, dec. 1997.

BALL, Ray; SHIVAKUMAR, Lakshmanan. Earnings quality UK private firms: comparative loss recognition timeliness. Journal of Accounting and Economics, v. 39. 2005. p.83-128.

BEAVER, William H. Financial reporting: an accounting revolution. 3rd ed. New Jersey: Prentice Hall, 1998.

BRASIL. Comissão de Valores Mobiliários (CVM). Ofertas registradas. Brasília, 2007. Disponível em: <http://www.cvm.gov.br>. Acesso em: 02/08/2008.

BURGSTAHLER, David C.; HAIL, Luzi; LEUZ, Christian. The importance of reporting incentives: earnings management in European private and public firms. The Accounting Review, v. 81, n.5, oct, p.983-1016, 2006.

CHOI, Frederick et al. International accounting. 3rd ed. New Jersey: Prentice Hall, 1999.

DARROUGH, Masako; RANGAN, Srinivasan. Do insiders manipulate earnings when they sell their shares in an initial public offering? Journal of Accounting Research, Oxford: v. 43, n.1, p.1-33, mar. 2005. 
DECHOW, Patricia M. Accounting earnings and cash flows as measures of firm performance: the role of accounting accruals. Journal of Accounting and Economics, New York: v. 18, n.1-2, p.3-42, jan. 1994.

; DICHEV, Ilia D. The quality of accruals and earnings: the role of accrual estimation errors. The Accounting Review, Sarasota, v. 77, n.4, supplement, p.35-59, oct. 2002.

DECHOW, Patricia M.; GE, Weili; SCHRAND, Catherine M. Understanding earnings quality: A review of the proxies, their determinants and their consequences. Journal of Accounting and Economics, New York: v.50, n. 2-3, p.344-401, dec. 2010.

Institute, 2004.

; SCHRAND, Catherine M. Earnings quality. Charlottesville (Virginia): CFA

; SKINNER, Douglas J. Earnings management: reconciling the views of accounting academics, practitioners, and regulators. Accounting Horizons, Sarasota: v. 14, n.2, p.235-250, jun. 2000.

FIELDS, Thomas D.; LYS, Thomas Z.; VICENT. Linda. Empirical research on accounting choice. Journal of Accounting and Economics, New York: v. 31, n.1-3, p.255-307, sep. 2001.

HEALY, Paul M.; WAHLEN, James M. A review of the earnings management literature and its implications for standard setting. Accounting Horizons, v. 13, n.4, p.365-383, 1999.

HOLTHAUSEN, Robert W.; WATTS, Ross L. The relevance of the value-relevance literature for financial accounting standard setting. Journal of Accounting and Economics, v. 31, 2001. p.3-75.

JONES, Jeniffer J. Earnings management during import relief investigations. Journal of Accounting Research, Oxford: v. 29, n.2, p.193-228, autumn, 1991.

KANG, Sok-Hyon.; SIVARAMAKRISHNAN, K. Issues in testing earnings management and an instrumental variable approach. Journal of Accounting Research, Oxford: v. 33, n.2, p.353-367, autumn 1995.

LI, Xu. Behavioral theories and the pricing of IPOs' discretionary current accruals. Review Quantitative of Finance and Accounting. Dordrecht: v. 37, n.1, p.87-104, jul. 2011.

LOPES, Alexandro B. A informação contábil e o mercado de capitais. São Paulo: Pioneira Thomson Learning, 2002.

; MARTINS, Eliseu. Teoria da contabilidade: uma nova abordagem. São Paulo: Atlas, 2005. 
MARTINEZ, Antônio Lopo. Gerenciamento dos resultados contábeis: estudo empírico das companhias abertas brasileiras. Tese (Doutorado em Ciências Contábeis) - Programa de Pós-Graduação em Ciências Contábeis, Departamento de Contabilidade e Atuária, Faculdade de Economia, Administração e Contabilidade da Universidade de São Paulo. São Paulo, 2001

; FARIA, Mariana de Paula. Emissão de debêntures e earnings management no Brasil. In: ENANPAD. 31., 2007, Rio de Janeiro. Anais... Rio de Janeiro, ANPAD, 2007. CD-ROM..

MERINO, Antonio P.; DÍAZ, Miguel A. R. SPSS 11: guía para el análisis de datos. Madrid: McGraw Hill, 2002.

MORSFIELD, Suzanne G.; TAN, Christine E. L. Do venture capitalists influence the decision to manage earnings in initial public offerings? The Accounting Review. Sarasota: v. 81, n.5, p.1119-1150, oct. 2006.

NIYAMA, Jorge K. Contabilidade internacional. São Paulo: Atlas, 2005.

PAE, Jinhan. Expected accrual models: the impact of operating cash flows and reversals of accruals. Review of Quantitative Finance and Accounting. Dordrecht: v. 24, n. 1, p.522, feb. 2005.

PAULO, Edilson. Gerenciamento de resultados e a oferta pública de ações pelas companhias abertas brasileiras In: ENANPAD. 30., 2006, Salvador. Anais... Salvador, ANPAD, 2006. CD-ROM.

Manipulação das informações contábeis: uma análise teórica e empírica sobre os modelos operacionais de detecção de gerenciamento de resultados. Programa de Pós-Graduação em Ciências Contábeis, Departamento de Contabilidade e Atuária, Faculdade de Economia, Administração e Contabilidade da Universidade de São Paulo. São Paulo, 2007.

; MARTINS. Eliseu. Análise da qualidade das informações contábeis nas companhias abertas. In: ENANPAD. 31., 2007, Rio de Janeiro. Anais... Rio de Janeiro, ANPAD, 2007. CD-ROM.

ROOSENBOOM, Peter; GOOT, Tjalling V. D.; MERTENS, Gerard. Earnings management and initial public offerings: evidence from the Netherlands. The International Journal of Accounting, v. 38, n.3, 2003. p. 243-266.

SCOTT, William R. Financial accounting theory. 3rd ed. Toronto: Prentice Hall, 2003.

SUBRAMANYAM, K. R. The pricing of discretionary accruals. Journal of Accounting and Economics, New York, v. 22, n. 1-3, p. 249-281, aug-dec. 1996.

TEOH, Siew H.; WELCH, Ivo; WONG, T. J. Earnings management and the long-run market performance of initial public offerings. Journal of Finance, v. 53, n. 6, p. 19351974, dec. 1998. 
YU, Frank. Analyst coverage and earnings management. Working Papers. University of Minessota, feb., 2006. Disponível em: <http://www.ssrn.com>. Acesso em: 03/12/2006

WATTS, Ross L.; ZIMMERMAN, Jerold L. Positive accounting theory. New Jersey: Prentice Hall, 1986.

WOOLDRIDGE, Jeffrey M. Introductory econometrics: a modern approach. 2nd ed. Ohio: South-Western College Pub, 2002. 